\title{
PERBEDAAN INDIVIDUAL SALAH SATU FAKTOR YANG PERLU DIPERHATIKAN DALAM PROSES BELAJAR MENGAJAR
}

\author{
H. Riduan Saberan \\ Program Studi Pendidikan Bahasa dan Sastra Indonesia \\ STKIP PGRI Banjarmasin
}

\begin{abstract}
Abstrak
Pendidikan merupakan salah satu bentuk realisasi atau perwujudan citacita bangsa yang dirumuskan di dalam pandangan hidup suatu bangsa. Untuk memahami pendidikan secara mendalam, banyak faktor perlu dipahami, antara lain meliputi faktor-faktor: cita-cita, anak didik, pendidik, alat dan lingkungan. Khusus faktor anak didik individual differences adalah salah satu faktor yang sering luput dari perhatian pendidik. Penelitian ini dilakukan dengan metode studi kepustakaan untuk mengetahui sebab-sebab individual differences perlu mendapat perhatian dalam proses mengajar belajar. Hal ini terlihat dengan penanganan tiap anak yang berbeda-beda dan untuk memenuhi prinsip individual ini ada beberapa cara yaitu: pengajaran indivdual, tugas tambahan, pengajaran proyek, dan pengelompokan menurut kesanggupan murid. Untuk itu setiap guru/pengajar dapat mengikuti perkembangan ilmu pengetahuan dan teknologi, terutama dibidang cara/metode mengajar, agar mutu pendidikan dapat ditingkatkan.
\end{abstract}

Kata kunci: perbedaan individual, proses mengajar-belajar

\section{PENDAHULUAN}

Pendidikan adalah usaha setiap bangsa yang dilakukan sepanjang masa. Melalui pendidikan yang diusahakan oleh setiap bangsa merupakan sarana tercapainya cita-cita bangsa. Pendidikan merupakan salah satu bentuk realisasi atau perwujudan cita-cita bangsa yang dirumuskan di dalam pandangan hidup suatu bangsa.

Dalam hal ini pendidikan merupakan alat bagi terlaksananya tujuan hidup yang pada masing-masing bangsa dapat ditinjau dari falsafah negaranya. Pendidikan selain merupakan alat bagi tercapainya sesuatu tujuan hidup bangsa, juga merupakan suatu cara mengubah keadaan bangsa itu sendiri dalam hal meningkatkan taraf kehidupannya, menyehatkan pandangan hdup warganya. Jadi pendidikan mengambil peranan yang sangat penting sekali.

Di dalam setiap pembangunan fisik atau mental tentu sangat mempengaruhi perkembangan pendidikan di dalam suatu negara. Seperti kita lihat sekarang di zaman pembangunan ini, pemerintah Indonesia sedang menjalankan program Pelita, dimana tidak ketinggalan pada pembangunan para pengajar). Kesemuanya ini adalah bertujuan meningkatkan mutu pendidikan.

Untuk memahami pendidikan ini secara mendalam, banyak hal-hal yang perlu dipelajari atau dipahami, termasuk bidang-bidang pendidikan yang menyangkut faktor-faktor pokoknya yang meliputi: faktor cita-cita, faktor anak didik, faktor pendidik, faktor alat dan faktor lingkungan. 
Perlu dikemukakan di sini anak sebagai faktor pokok, karena dari anaklah kita bisa menerapkan pendidikan secara mendasar dan tidak meninggalkan menurut bakat kemauannya. Hal ini dikatakan demikian karena tiap anak sebagai individu tidak ada satupun yang memiliki hal-hal yang sama antara anak yang satu dengan anak yang lainnya, baikditinjau dari segi fisik maupun mentalnya dalam artian tiap individu berbeda dengan individu lainnya. Juga disebabkan oleh karena pembawaan, lingkungan dan intelegensi yang berbeda-beda.

Sehubungan dengan itu, peneliti memilih judul tentang "Perbedaan Individual Salah Satu Faktor yang Perlu Diperhatikan dalam Proses Belajar Mengajar".

\section{METODE}

Menurut jenisnya metode penelitian ini sangat banyak sekali, sesuai dengan lapangan yag diteliti. Biasanya setiap orang yang terjun ke lapangan atau objek penelitian baik secara individu maupun kelompok haruslah menentukan metode apa yang digunakan dalam rangka mengumpulkan data yang diperlukan sebelum langkah-langkah penelitian dimulai, sebab kalau tidak demikian penelitian tersebut akan sulit dalam memenuhi tujuannya, maka sebelumnya kita harus mengerti dan menguasai tentang metodologi dalam melakukan penelitian.

Adapun metode peneitian yang peneliti gunakan dalam menyusun laporan penelitian ini ialah penelitian perpustakaan (Library Research), dimana data atau informasi diperoleh melalui buku-buku, majalah, naskah, catatan dan sebagainya. Hal ini menurut hemat peneliti untuk memudahkan dan mengurangi waktu, tenaga dan biaya dalam penulisan laporan penelitian ini.

\section{PEMBAHASAN}

\section{A. Beberapa Faktor yang Menyebabkan Perbedaan}

\section{Lingkungan}

Lingkungan sekitar ialah lapangan-lapangan pendidikan yang terdiri atas tiga macam: lingkungan keluarga, sekolah dan masyarakat.

\section{a. Lingkungan Keluarga}

Keluarga adalah inti masyarakat. Di sinilah anak didik mulai mengenali kehidupan dan pendidikannya. Keadaan anak didik sebelum lahir telah ditentukan oleh faktor-faktor keturunannya atau warisan yang didukung oleh keluarganya mengenai kejasmanian dan keroahaniannya. Kemudian dengan kelahirannya dimulailah pengaruh-pengaruh luar yang menghambat atau menyuburkan benihbenih yang ada. Banyaklah dasar-dasar kelakuannya tertanam sejak dalam keluarga, sikap hidup, kebiasaan-kebiasaan. Faktor luar dari orangtuanya tidak sedikit pengaruhnya terhadap pendidikan, ekonomi, adat istiadat, keadaan orang tua sendiri sebagai seorang, kesempatan-kesempatan dan cara pemuasanpemuasan dirinya.

\section{b. Lingkungan Sekolah}

Dahulu segala yang diperlukan anak-anak untuk kehidupannya di kemudian hari, harus dipelajarinya di rumah atau di masyarakat. Hal seperti ini masih terdapat di beberapa daerah. Tetapi setiap orang mengakui, bahwa 
persiapan bagi masyarakat yang modern meminta pendidikan yang dipengaruhi oleh sekolah.

Sekolah adalah membantu orang tua mengerjakan kebiasaan-kebiasaan baik dan menanam budi perkerti yang baik, melatih mereka memperoleh kecakapan-kecakapan seperti membaca, menulis, berhitung dan sebaganya. Sekolah juga mengajar anak-anak menghargai keindahan, membedakan yang benar dan yang salah.

\section{c. Lingkungan Masyarakat}

Lingkungan masyarakat merasa bertanggung jawab atas keberesan perkara-perkara di masyarakat. Pemikul tanggung jawab itu ialah penduduk. Sumbangan pendidikan oleh masyarakat kepada pendidikan amat penting artinya. Anak-anak belajar, bahwa di luar lingkungan keluarga, ada pula orang yang mempunyai hak milik orang sekelilingnya dan bersifat sabar terhadap anak-anak di masyarakat itu. Mereka belajar, bahwa mereka berkewajiban juga terhadap orang lain, yaitu tolong-menolong, pinjam-meminjami alat-alat pekerjaan dan barang-barang lain.

Kerjasama dan tolong menolong, juga dalam suka dan duka, akan menghasilkan buah yang sangat baik dalam masyarakat; di sana tak akan terdapat perbedaan-perbedaan yang terlalu besar antara kaya dan miskin, tinggi dan rendah. Dala masyarakat seperti itu anak-anak muda akan lepas belajarapa-apa yang disebut dengan demokrasi yaitu kerjasama berdasarkan persamaan hak dan kewajiban dalam hidup bersama.

Di kota besar pendidikan lingkungan kampung itu tidak mendapat tempat yang sebagaimana mestinya. Pekerjaan lingkungan itu haruslah digantikan oleh lingkungan lain. Dalam hal ini bagaimana corak dalam lingkungan sedikit banyaknya mempengaruhi kepada tiap-tiap individu, yaitu macam-macam pengaruh dalam lingkungannya, seperti:

a. Anak itu bergaul dengan teman-temannya dan peraulan itu sangat mempengaruhi jiwanya. Ia mendapat pengalaman-pengalaman dari teman-temannya di jalan, di sekolah, dalam perkumpulanperkumpulann dan di rumah temannya

b. Lain daripada gurunya, ia bergaul pula dengan orang dewasa yang lain, yaitu denngan kaum kerabatnya

c. Lingkungan rumah yang kadang-kadang sangat berbeda-beda, berpengaruh pula pada anak

John Dewey mengemukakan: di dalam keadaan integrasi manusia dengan lingkungannya inilah manusia menerima semua kesempatan untuk perkembangan kepribadiannya.

\section{Pendidikan}

Adapun mengenai pendidikan yang peneliti maksudkan di sini ialah semua anak mempunyai kemauan yang sama, namun karena taraf kemampuan bakat IQ berbeda-beda, maka dalam pendidikan pun ada perbedaan.

Dalam hal ini ahli-ahli pendidikan dan ilmu jiwa telah memperhatikan adanya: Perbedaan kecakapan belajar secara teliti dan mengusahakan penyesuaian isi pengajarandengan ingkat kemampuan yang berbeda-beda. Maksudnya adalaha agar anak didik dengan keadaaan kemampuannya dapat mengambil sebanyak 
mungkin keuntungan-keuntungan pendidikan serta mengembangkan kemampuannya sejauh mungkin dalam batas kemampuannya.

Kecakapan belajar yang disebutkan dengan kecerdasan ialah sebagai suatukecakapan seseorang untuk menyesuaikan diri dengan keadaan yan dihadapinya.

\section{Makanan}

Beberapa faktor yang menyebabkan perbedaan termasuk diantara makanan, makanan adalah salah satu keperluan pokok yang lebih penting bagi manusia. Penulis maksudkan makanan sebagai penyebab faktor perbedaan individu di sini, karena dari sekia banyak makanan tersebut ada yang berguna bagi pertumbuhan dan perkmbangan individu dalam artian mempunyai gizi dan ada pula yang tidak berguna bagi pertumbuhan dan perkembangan individu tidak mengandung gizi.

Gizi dapat diartikan sebagai ilmu mengenai memberi makan tumbh dengan baik, arinya menyediakan cukup segala keperluan bagi pertumbuhan, pemeliharaan dan reperasi.

Dalam hal ini marilah kita ikuti penyelidikan Mc Carrison yang menyelidiki tentang makanan rakyat iberbagai bagian India dalam hubungannya dengan kesehatan suku-suku bangsa yang bersangkutan.

Di bagian-bagian selatan makanan terutama terdiri dri beras giling, buah dan sayur dengan sedikit daging atau susu; penduduk di daerah-aerah ini berperawakan kecil, tenaga kurang dan berumur pendek. Suku-suku disebelah utara, yang makanannya terdiri dari cantel dan gandum yang tidak digiling dengan susu kambing dan mentega, mempunyai keadaam jasmani yang bagus dan cocok untuk menjadi prajurit yang baik.

Di bagian-bagian yang jauh di pegunungan Himalaya terdapat bangsabangs dengan keadaan makanan yang sederhana, sebagian besar terdiri dari aprikat (dikeringkan dimatahari untuk peperluan musim dingin) sayur mayur dan susu kambing, daging hanya dimakan pada waktu hari-hari pesta, penduduk di sini luar biasa kuatnya, sehat dan panjang umurnya.

Dari hasil penyelidiakan di atas terlihat bahwa makanan sangat mempengaruhi dan menyebabkakan perbedaan individu dalam perkembangann dan pertumbuhannya.

\section{Usia}

Dengan usia seseorang meningkat dan masak dalam pengalamanpengalamannya yang diberikan oleh pengaruh sekitarnya baik yang menguntungkan merugikan akan menimbulkan suatu perkembangan di dalam sikap dan kelakuannya.

Anak-anak se usia lima tahun, lima belas tahun, dan orang dewasa dalam usia tiga puluh lima tahun ketiga-tiganya berbeda. Peredaannya bukan karena asal usul atau lingkungan, melainkan tingkat perkembangan dan kemasakan jiwanya yang dinilai dari usia tahunnya. Kalaupun perbedaan itu tidaklah melalui urutan perkembangan yang normal. Hal ini sudah dijelaskan di dalam usia-usia perkembangan yang ternyata merupakan masalah dalam pendidikan yang menginginkan pelayanan yang tepat bagi tiap anak didik sesuai dengan tingkattingkat perkembangan jasmani, jiwa, emosi, pendidikan dan sosialnya. 


\section{B. Beberapa Cara untuk Memenuhi Prinsip Individualitet}

1. Pengajaran Individual

Pada uraian ini dibedakan dua macam pengertian tentang pengajaran individual itu. Pertama, pengajaran individual atau pengajran perseorangan adalah penagajaran yang diberikan kepada anak seseorang. Lawannya ialah pengajaran yang diberikan kepada anak seseorang. Lawannya adalah pengajaran klasikal, yaitu pengajaran yang diberikan kepada serombongan murid-murid bersama-sama pada sebuah kelas.

Dengan bentuk pengajaran itu tiap-tiap anak dimajukan menurut kecepatannya masing-masing, dengan pengertian pengajaran disesuaikan dengna kebutuhan dan kesanggupan anak-anak itu masing-masing.

Kedua, pengajaran individual adalah pengajaran yang diselenggarakan sedemikian rupa sehingga tiap-tiap siswa terlibat setiap saat dalam proses belajarnya itu dengan hal yang paling berharga bagi dirinya sebagai individu.

Pengajaran individual merupakan usaha untuk menyajikan kondisi-kondisi belajar yang optimum bagi masing-masing individu.

Dalam pengertian yang kedua ini dimaksud dengan pengajaran indiviual bukanlah semata-mata pengajaran yang hanya ditujukan kepada seseorangseseorang saja. Melainkan pengajaran itu dapat saja ditujukan kepada sekelompok siswa (kelas) namun dengan mengakui dan melayani perbedaan-perbedaan perseorangan siswa sedemikian rupa sehingga pengajaran itu memungkinkan berkembangnya potensi-potensi masing-masing siswa secara optimal.

Pokoknya di sini memberi kebebasan kepada setiap aak untuk majumenurut kecepatan masing-masing. Anak-anak yang ber IQ 150 tentu lebih cepat belajar daripada anak yang hanya IQ nya 90. Dengan cara ini dicapai dengan sistem tugas. Bahan pelajaran dibagi dalam tugas mingguan untuk berbagai-bagai mata pelajaran. Bila suatu tugas selesai anak boleh menerima tugas baru.

Tugas-tugas ini bersifat self-intructive. Tugas ini biasanya dicetak atau distensil. Anak-anak harus membaca sendiri instruksi atau petunjuk-petunjuk tentang cara melakukan tugas itu, sedapat mungkin tanpa bantuan dari pihak guru. Kadang-kadang tugas itu juga self-corrective, artinya berisi jawaban sehingga anak itu dapat memeriksa pekerjaannya sendiri.

Nah akibat dari sistem ini ialah bahwa anak-anak tidak naik kelas pada waktu yang sama. Sekolah ditempuh menurut kesanggupan dan kerajinan masingmasing.

Pengajaran individual serupa itu antara lain dilakukan dalam Dalton Plan (Miss Helen Parkhust), Winnetku Plan dan lain-lain. Di sini akan dibicarakan sedikit tentang Winneku Plan yang iselenggarakan oleh Corleton W. Wekhburne di Winenetku suatu kotak kecil dekat Chicago.

Dalam hal ini ia membagi bahan pelajaran di atas:

a. Common essentials, yakni mata pelajaran biasa seperti ilmu bumi, sejarah, berhitung, ilmu alam dans sebagainya. Bahan inilah yang diberikan berupa tugas. Di sinilah nak-anak maju menurut kecepatan masing-masing.

b. Creative and group activities, yakni pelajaran ekspresi (bernyanyi, menggambar dan sebagainya). Jadi segi sosial tidak diabaikan. 
Hasil Winnetku Plan, diselidiki tamatan cara pengajaran ini ternyata tamatan W Lebih efektif pada sekolah lanjutan. Mereka lebih sanggup belajar sendiri.

Walaupun hasilnya baik, Winnetku Plan tidak berapa banyak dilakukan begitu juga halnya dengan Dalton Plan.

Karena adanya berbagai macam keterbatasan: waktu, biaya, perlatan, dan sumber-sumber lainnya, maka cita-cita sistem pengajaran individual secra urni itu tidak penuh tercapai. Bahkan andaikata guru hanya melayani seorang siswa pun, di tidak dapat menyelenggarakan penajaran indiviual itu, karena tidak mungkin dia mampu mengenal semua kebutuhan siswanya serta menyelenggarakan program dan perlengkapan yang dierlukan bagi pemenuhan siswa tersebut.

Dasar pikiran pengajaran individual ialah adanaya pengakuan terhadap perbedaaan individual pada masing-masig siswa. Apabila pengajaran klasikal menekankan pada persamaannya, maka pengajaran individual lebih menekankan pada perbedaan individual siswa. Nah untuk memenuhi prinsip ini di dalam penyajian bahan pelajaran kita harus memperhatikan juga adanya perbedaan individual dalam menerima pelajaran. Setiap siswa mempunyai intelegensi, daya tangkap dan kemampuan yang tidak sama. Karena itu baik bahan pelajaran mauun cara-cara/gaya penyampaiannya haruslah disesuaikan dengan situasi dan kondisi siswa itu sendiri.

Untuk mengadakan penyesuaian dengan pebedaan-perbedaan individual ini kita mngabil patokan/pedoman tingkat kecerdasan/kemampua yang normal (sedang). Bahan pelajaran disusun sedemikian rupa sehingga jangan terlalu mudah dan jangan pula terlalu sulit.

Demikian pula pada waktu kita mempersiapkan bahan pelajaran kita harus sudah memperhitungkan level (tingkat) kemampuan siswa.

\section{Tugas Tambahan}

Dalam tugas-tugas tambahan ini anak-anak belajar tetap dalam hubugan kelas yang pada dasarnya menerima pelajaran yang sama. Kepada anak-anak yang pandai diberi tugas tambahan sesuai dengan kesanggupan dan kecepatannya masing-masing.

Menurut tingkat kesukarannya ada tiga jenis tugas: tugas minim, sedang (normal), dan tugas maksimum. Setiap anak harus menyelesaikan tugas minim, akan tetapi bagi murid yang cepat selesai dapat menyelesaikan tugas-tugas yang sedang dan yang maksimum. Tugas-tugas yang diberkan dpat berbentuk individual maupun tugas kelompok.

a. Tugas harus disesuaikan kapasitas anak masing-masing

b. Tugas itu harus berbeda baik secara kuantitatif maupun kualitetnya

c. Tugas itu harus bersifat problematis dan jangan hanya berisi faktafakta hafalan saja.

d. Tugas itu hendaknya berisi demonstrasi ekperimen atau pemecahanpemecahan masalah serta bermacam-macam aktivitet

e. Tugas harus dapat membangkitkan motivasi dan aktivitet anak

f. Tugas harus jelas dan mudah dipahami anak 


\section{Pengajaran Proyek}

Suatu proyek biasanya terdiri dari suatu masalah yang luas yang dianggap murid-murid vital dan berharga baginya; sehingga ia giat mengerjakannya atas dorongan diri sendiri untuk mencapai tujuan yang terkandung dalam proyek tersebut.

Proyek itu dipecahkan dalam beberapa bagian. Tiap anak memilih bagian yang sesuai baginya, jadi sesuai dengan perbedaan indovidual. Juga dalam pelaksanaan selanjutnya banyak terbuka kesempatan untuk kebebasan individual, sehingga tiap anak dapat bekerja menurut kesanggupa dan bakat masing-masing.

Dalam proyek tidak diharapkan agar anak mempelajari bahan yang sama dalam jumlah yang sama. Malahan tiap anak memperoleh dan mengerjakan hal yang lain dalam proyek itu. Selain dari pada itu mungkin dikemukakan dan dikembangkan bakat-bakat khusus dalam pengajaran proyek ini.

Di sini peneliti hanya mengemukakan bahwa pengajaran proyek adalah sebagian cara untuk memenuhi prinsip individualitet.

\section{Pengajaran Murid}

Dalam sistem klasikal, penyesuaian pengajaran dengan perbedaan individual harus diusahakan untuk mengelompokkan anak-anak yang pandai, ssedang dan yang kurang, misalnya mengelompokkan anak-aak yang ber IQ rendah, normal dan yang tinggi. Dengan mengelompokkan ini kita memperoleh apa yang disebut dengan "homogenious grouping".

Akan tetapi mengingat perbedaan-perbedaan antara anak, sehingga tak ada dua orang yang persis sama, maka jelaslah bahwa pengelompokan seperti itu tak mungkin dilakukan. Walaupun dua orang anak ber IQ sama besar, kemungkinan meraka tidak sama dalam komonen-komponen kegiatan-kegiatan daripada intelegensi masing-masing.

Di dalam kelas anak-aak dapat pula dibagi dalam beberapa kelompok menurut kepandaiannya yang disebut "abilitty grouping" misalnya kelompok pandai, sedang dan kurang pandai.

Dengan demikian pelajarandapat disesuaikan dengan kesannggupan tiap kelompok.

Mengajar anak-anak yang kurang pandai

Kelompok anak-anak ini kurang cepat memahami, kurang abstrak berpikir, kurang tajam menghayal, kurang pandai mengingat, mengasosiasi, menganalisa dan menafsirkan sesuatu. Karena itu dalam mengajar harus diperhatikan hal-hal sebagai berikut:

a. Pengajaran harus lebih konkret, banyak memberikan pengalaman langsug, banyak diragakan

b. Pelajaran harus lebih banyak diulang, akan tetapi diusahakan pengertian lebih dahulu

c. Dalam mengerjakan harus diadakan variasi, selingan dan motivasi, karena perhatian mereka kurang lama, dan kepada mereka harus lebih banyak diberikan aktivitas jasmaniah

d. Dalam menghadapi anak-anak ini guru haeus sabar, ramah dan antusias. Meereka harus lebih banyak memerlukan bimbingan dan jangan dipaksa belajar melebihi dari kesanggupannya. 
Mengajar anak-anak yang pandai. Dalam segala hal anak-anak kelompok ini lebih cepat dalam proses belajarnya. Mereka selalu ingin tahu dan suka mengajukan pertanyaan. Minat mereka luas, dapat berpikir abstrak dan mudah melihat hubungan sesuatu. Karena itu dalam mengajar:

a. Bahan pelajaran harus ditambah, kuantitatif dan memperdalam pengetahuannya

b. Anak-anak ini dibimbing belajar sendiri, menggunakan buku-buku perpustakaan, kamus, atlas, dan sumber-sumber lain. Anak-anak ini maju menurut kecepatannya masing-masing

c. Anak-anak dihadapkan dengan masalah-masalah, karena anak-anak itu sanggup memecahkannya. "Problem Solving" harus diutamakan sebagai cara belajar

d. Anak-anak ini tidak banyak memerlukan latihan dan ulangan, karena mempunyai ingatan yang baik

e. Anak-anak tak perlu diberi banyak alat peraga karena lebih sanggup berpikir abstrak

Mengajar anak-anak sedang

Dengan pengetahuan cara-cara mengajar anak yang kurang dan yang pandai, kita dapat menyesuaikan pelajaran kepada kesanggupan anak-anak yang sedang di mana kedudukannya diantara kedua golongan tadi.

Dalam hal ini perlu diingat, bahwa dalam pembagian kelompok-kelompok itu harus diusahakan jangan sampai menimbulkan adanya rasa harga diri lebih (superioritet) dan harga diri kurang (inverioritet) diantara anak. Perasaan harga menghargai dan kerjasama masing-masing tetap dipupuk dan dikembangkan dalam hubungan kelompok dan kelas.

Frekuensi pemakaian cara-cara penyesuaian pelajaran dengan perbedaan individu. Dalam penyelidikan terhadap 8594 sekolah R.O. bilet dalam monogram. Provisions for Individual differences, marking and promotion 1932. Ternyata ada 28 macam cara tersebut dapat dikategorikan dalam tujuh kategori:

1. Pengelompokan homogen

2. Pembentukan kelas istemewa

3. Pengajaran unit atau proyek

4. Penyelidikan ilmiah tetanng anak-anak yang memenuhi kesukaran

5. Perbedaan tugas untuk murid-murid

6. Pengajaran di luar sekolah

7. Program guidance yang memberi bimbingan kepada anak-anak

Dalam hal pengelompokan ini Dr. Ny. Supartinah fakar dalam metodologi pengaaran dinamakan "achievement grouping".

\section{PENUTUP}

\section{Simpulan}

Berdasarkan pada uraian-uraian yang telah peneliti kemukakan dalam babbab sebelumnya, maka dapatlah peneliti menarik kesipulan sebagai berikut:

1. Pendidikan di Indonesia dewasa ini menghendaki peningkatan mutu pendidikan. Dalam hal ini penyempurnaan metode mengajar adalah bagian dari mutu pendidikan 
2. Cara mengajar adalah ilmu yang prakatis untuk dipakai sehari-hari oleh guru sebagai penerapan prinsp-prinsip psikologis dan azas-azas pedagogik terhadap perkembangan murid

3. Setiap anak atau murid atau dengan istilah lain individu atau perorangan selalu berbeda-beda, baik ditinjau dari segi fisik maupun mentalnya

4. Dalam proses belajar mengajar seorang guru selalu berhadapan dengan murid yang berbeda-beda baik mengenai bakat/intelegensi sebagai pembawaan/dasar atau lingkungannya

5. Demikian pula mengenai tempo dan irama perkembangan dari tiap-tiap anak/individu tersebut selalu berbeda-beda

6. Dengan adanya perbedaan individu (Individual differences) seperti tersebut di atas maka dalam kegiatan mengajarbelajar guru harus memperhatikan perbedaan tersebut dengan metode mengajar yang dipergunakan

7. Demikianlah betapa pentingnya peranan guru/pengajar dalam memperhatiakn perbedaan individu /anak dalam hal proses belalar mengejar

8. Berhubung tiap anak berbeda-beda, maka untuk memenuhi prinsip individu ini ada beberapa cara yaitu: pengajaran individual, tugas tambahan, pengajaran proyek dan pengelompokan menurut kesanggupan murid

\section{Saran}

Dengan beberapa kesimpulan tersebut di atas peneliti bermaksud akan menyambungkan beberapa pikiran yang berupa saran-saran yang berhubungan dengan beberapa kesimplan di atas sebagai berikut:

1. Dalam ragka untuk mendapatkan hasil pendidikan yang baik, seorang guru harus matang persiapan fisik maupun mental

2. Setiap guru/pengajar dapat mengikuti perkembangan ilmu pengetahuan terutama dibidang cara/metode mengajar agar mutu pendidikan dapat ditingkatkan

3. Setiap guru yang mengajar jangan melulu mengajar saja, dalam hal ini harus memperhatikan situasi dan kondisi murid (perbedaan) murid.

\section{DAFTAR PUSTAKA}

Abu, A. 1978. Didaktik Metodik. Semarang: CV Toha Putra

Arrahman. 2013. Belajar dan Pembelajaran Cetakan Kedelapan. Bandung: Alfabeda.

Djapri, B. 1977. Diktat Didaktit Metodik. Banjarmasin; FKIP Unlam.

Iskandar, R, DE dan R Soehartanto.1977. Metodik dan Didaktik. Banjarmasin; FKIP Unlam.

Jean B, L, B, Napitupulu. Gizi dan Kesehatan Jasmanni. Bandung: Genta Ilmu. 
Mursell, J,L,S, Nasotion. Successful Teaching. Bandung: Jammars IKIP.

Nasotion, S, R, M, Thomas. Buku Penuntun Membuat Disertasi, Thesis, Skipsi, Report Paper. Bandung: Jammars IKIP.

Didaktik Azas-Aas Mengajar. Bandung: Jammars.

Rusman. 2010. Model-Model Pembelajaran. Cetakan Keempat.

Rusman. 2013.Belajat dan Pembelajaran Berbasis Komputer Cetakan Kedua. Bandung: Alfabeda.

Sabri, A. 2010. Micro Teaching. Cetakan ketiga.

St.Vebbriarto. 1976. Pengajaran Modul. Yogyakarta; Yayasan Pendidikan Paramita.

Siti M. 1976. Pendidikan Sistematis. Cetakan ke XI. Yogyakarta; Fip IKIP.

Sudirjo. 1977. Metodologi pengajaran. Yogyakarta; Perpustakaan IKIP.

Sutikno, S. M. 2009. Belajar Pembelajaran. Cetakan kelima.

Witherington, H, C. 1978. Psychology Pendidikan. Jakarta: Aksara Baru.

Winarno, S. 1973. Dasar dan Teeknik Interaksi Mengajar dan Belajar. Bandung: Tarsito. 